\title{
Stability of Pain Measures in a Different Stimuli Context
}

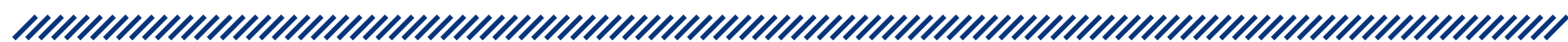

1 Koraljka Modić Stanke

1 Department of Psychology, Faculty of Humanities and Social Sciences, University of Zagreb, Zagreb

\section{Abstract

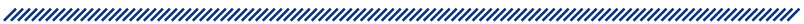

Pain in any context is always associated with high interand intra-individual variability. There are several paininducement methods and numerous pain measurement methods at researchers' disposal in experimental settings; since none of them is without limitations, the increasing number of researchers decides upon a multimethod approach. In doing so, clarity and unambiguity of the results may vary - depending on the reliability of the certain method in a specific stimuli context.

The aim of this study was to explore the stability of the pain perception in the same subject sample - between different pain contexts and also within the same one. 52 female students participated in three methodologically identical repeated measurements, conducted a week apart. The pain was experimentally induced in two different ways - first by thermal and then by electrical stimuli. Participants reported on pain threshold and tolerance during stimulation and assessed pain intensity and unpleasantness right after each stimulation.

Results demonstrated that the stability of pain perception depends on both the stimuli context and the type of pain measurement. Pain experience was proven to be more stable in thermal-stimuli context, where pain threshold and tolerance remained unchanged in all repeated measurements. In electrical-stimuli context pain threshold and tolerance successively increased with each following measurement. In both pain modalities, the assessment of the pain unpleasantness increased with each measurement, while the assessment of the pain intensity remained unchanged. Observed contextual differences could be due to different familiarity with specific pain stimuli context and different level of anxiety associated with it.

Keywords: stability of pain perception, pain threshold, pain tolerance, pain unpleasantness, pain intensity, thermal and electrical stimuli

Article received: 11.11.2016.

Article accepted: 01.04.2017.

DOI: $10.24141 / 3 / 1 / 3$

Corresponding author:

Koraljka Modić Stanke

University of Humanities and Social Sciences

Ivana Lučića 3, 10000 Zagreb

E-mail:kmstanke@ffzg.hr

Tel: +38514092378 


\section{Introduction}

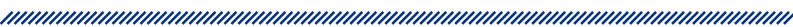

Pain is always a subjective experience - the same stimuli can make one person cry out in pain and at the same time be barely noticed by another. The very same injury can seem life-threatening to someone in a given moment and elicit some entirely different sensations when experienced again. These large inter- and intraindividual differences are associated with a number of different dispositional and situational factors and, of course, their interaction. Accordingly, age ${ }^{1-2}$, gender ${ }^{3-4}$, experience ${ }^{5-6}$, attention ${ }^{7-8}$, expectations ${ }^{9-10}$, but also environmental ${ }^{11-12}$ and social context ${ }^{13-14}$ are just a few of the many factors one must take into account when conducting a pain research.

Pain studies can be conducted within realistic clinical conditions or in the controlled experimental settings. Some researchers prefer experimental conditions because increased control diminishes the influence of several factors affecting pain experience and therefore reduces previously mentioned variability. When conducted in control settings, pain studies usually imply experimental inducement of acute pain. There are numerous methods of pain inducement but chemical ${ }^{15}$, mechanical ${ }^{16}$, thermal ${ }^{17}$ and electrical ${ }^{18}$ stimuli are most frequently used - none without its limitations. Additionally, while still in search for an accurate physiology-based pain measures ${ }^{19}$, a number of subjective pain measurement methods are available pain threshold and tolerance along with the assessment of pain intensity and unpleasantness are just a few of many, commonly used in the experimental settings. All of them, much like the pain-inducement methods, have their advantages and disadvantages, and some researchers advocate the use of the multi-method approach ${ }^{20}$ in order to get a better insight into the complex phenomenon of the pain perception.

A trend of the increasing number of multi-method pain studies can be found in the literature, with both multiple methods of pain inducement and multiple methods of pain measurement present within a single study. Although this approach may contribute to a more valid and general conclusion, researchers are advised to carefully consider the characteristics, compatibility, and stability of the methods they want to use in the same study. Accordingly, the aim of this study was to explore the stability of the pain perception - between different pain modalities and also within the same one, with an effort to investigate both reliability and validity of the pain experiments.

In the present study, two qualitatively very different pain-inducement methods were used: a) thermal stimuli, well-known to evoke natural sensation and b) electrical stimuli, proven to produce non-natural sensation, to find out will the same participants perceive them in the same way. Additionally, four pain measurement methods were used - pain thresholds and tolerance and also the assessment of pain unpleasantness and intensity, to test their stability during a period of time, and also their compatibility considering two pain-inducement modalities. Some authors believe that different pain modalities represent different dimensions of pain perception ${ }^{21}$, so low to moderate correlations were expected between each pair of pain measures in the two pain inducement modalities. With regards to the stability of the pain perception, it was hypothesized that all measures would be stable within the same modality during a period of time.

\section{Method}

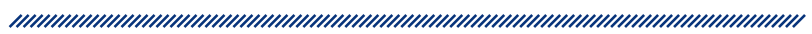

This research followed the ethical principles for conducting research with human participants and was approved by the local Ethical Committee. Participation in the study was voluntary and the participants were thoroughly informed about every aspect of the research procedure before they provided their written consent.

\section{Participants}

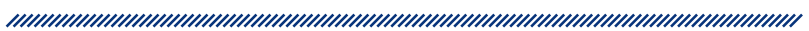

Participants were 52 healthy psychology students between the ages of 18 and 22 who volunteered to participate in a pain study and were adequately rewarded for it. Because of gender differences in pain tolerance ${ }^{4}$ and possible interaction of experimenter's and participants' gender ${ }^{22}$, all participants in this study were female. To control the possible effects of the experimenter's characteristics ${ }^{23}$, the experiment was conducted by a single female experimenter. 


\section{Pain stimulation}

Thermal stimulation was induced by the flow of hot air; although the pain was induced by continuous sametemperature thermal stimuli, participants perceived different pain experience during measurement (ranging from sensing warmth to impossible-to-endure pain) due to temporal summation of noxious stimuli. Thermal stimuli were presented on the palm of volunteer's left hand, fixated in a tube set eleven centimeters from the heat source. The purpose of this hand fixation was to prevent hand movement during unpleasant stimuli and to ensure constant distance from the source of hot air to a participant's hand. The tube had a gap size $3.5 \times$ 1.8 centimeters which limited the stimulated area. The temperature of thermal stimuli was limited to $55^{\circ} \mathrm{C}$ at the source and duration of thermal stimuli was, due to safety reasons, limited to 120 seconds.

Electrical stimuli were induced by two electrodes set on the index finger and the ring finger of the volunteer's right hand, using the DS5 isolated bipolar stimulator (Digimeter Ltd, United Kingdom) that allows computer control of stimulus amplitude and timing parameters. The computer program was designed to allow a stimulation range from 0 to 255 units (equal to the maximum constant current output of $10 \mathrm{~mA}$ ). Sequenced stimuli were generated several seconds apart, each 5 units (about $0.20 \mathrm{~mA}$ ) surpassing the previous one. During electrical stimulation, a participant's right hand was placed on the table in front of the subject.

\section{Measures}

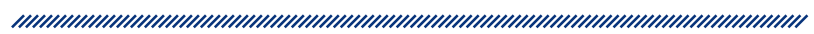

When in thermal context, participants were asked to verbally report the development of pain sensation and to state when thermal stimuli would change on the continuum: warm - hot - scorching - painful - non-endurable pain (at which point the subject would stop unpleasant stimuli). Pain threshold in thermal context was defined as the time (in seconds) elapsed from the beginning of thermal stimulation till the moment participant stated the stimuli become painful. When in the electrical con- text, participants were asked to assess each of the following stimuli on the scale from 0 to 10 ( 0 - no pain; 10 - non-endurable pain). Pain threshold in electrical context was defined as the amount of constant current output (in $\mathrm{mA}$ ) related to the lowest electrical stimuli participant declared to perceive as painful i.e. after which participant for the very first time changed the statement to other than "non-painful stimuli" (assessment that was different from 0 ).

In both modalities, participants were instructed to endure pain as long as they could and to stop stimuli (behaviorally in the case of thermal stimuli or verbally in the case of electrical stimuli) when they could not take it anymore. Pain tolerance in thermal context was defined as the time (in seconds) elapsed from the beginning till the end of thermal stimulation. Pain tolerance in electrical context was defined as the amount of constant current output (in $\mathrm{mA}$ ) related to the highest electrical stimuli participant was willing to endure. After each pain modality, participants were asked to give their assessment of a) pain unpleasantness during the entire painful experience and b) pain intensity at its' peak (just a moment before the participant stopped pain inducement). Assessments were given on the scale from 0 to 10 (0 - not unpleasant/minimal intensity; 10 entirely unpleasant/maximal intensity).

\section{Procedure}

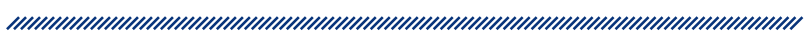

Each participant underwent three methodologically identical measurements. To avoid possible influence of memory, the time interval between two adjacent measurements was one week. To control for the possible effect of the circadian rhythm, all participants attended measurements at the same time of the day.

Upon a participant's arrival to the first measurement, the researcher introduced her to the experimental procedure and then escorted her to a soundproof room where all measurement occurred. The researcher asked her some questions about her current health and emotional status and measured her blood pressure and body temperature. To avoid "the good-subject effect", participants were presented with a fictive goal of research - to investigate the physiological reactions (body temperature, blood pressure, heart rate, respira- 
tion) to the painful experience. Thus, although blood pressure, heart rate, respiration and body temperature were monitored, these measures were not taken into account during data analysis. The experimenter placed the electrodes for monitoring physiological reactions (pulse, respiration) onto the participant, and additionally explained the experiment procedure in detail. All participants first underwent thermal pain stimulation and then electrical pain stimulation. The experimenter was never present in the room during painful stimulation, but she could communicate with participants (and was also able to hear their verbal reactions to painful stimuli) over the interphone.

Since measurements took place in the winter period, a participant's hands were heated for several minutes (till they reached normal body temperature) before the thermal pain stimulation, to control for the difference between skin temperatures of all participants. Participants controlled the start and the end of thermal stimuli by themselves. Their task was to endure painful stimulation for as long as they could. If the subject did not turn off the apparatus during 120 seconds of stimulation, the task was terminated by the experimenter. Participants were not previously informed about this time limit. During thermal stimulation, participants' task was also to monitor their sensations and to verbally report about their present pain experience. Immediately after thermal stimulation was completed, participants were asked to rate the intensity and unpleasantness of thermal pain experience. Between thermal and electrical painful stimulation participant completed one questionnaire.

To enable the electrical stimulation the researcher first treated a participant's finger with alcohol in order to reduce the impedance and then placed electrodes on a participant's right hand and explained the following procedure. Since the stimulation in this context was not constant (stimuli were elicited successively every few seconds and increasing with every following stimulus) each participant was notified each time she was about to receive the next stimuli. A participant's task was to rate the sensation (from 0 - no pain; to 10 - non-endurable pain) after each electrical stimuli. She was instructed to endure painful stimulation for as long as she could, and to give the highest assessment (10) when she wants the stimulation to stop. If the subject was not about to stop stimulation before, experimenter ended the experiment when the amount of constant current output (in $\mathrm{mA}$ ) reached highest possible level (10 mA). Participants were not previously informed about this limit. Immediately after electrical stimulation was completed, participants were asked to rate the intensity and unpleasantness of electrical pain experience.

\section{Results and Discussion}

The present study was conducted with one primary goal - to verify the cross-context stability of the pain perception. Since this problem can be divided into two sections - the stability between different pain contexts and the stability within the same context (i.e. repeated measurement) - several analyses were conducted, one for each dependent variable measured and one for each pain-inducement situation in this experiment.

To investigate whether pain perception is stable throughout the same context, repeated measures ANOVA was conducted for all four dependent variables in both thermal (results are presented in Figure 1. and 2.) and electrical pain context (results are presented in Figure 3. and 4.). Within thermal pain context there were no statistically significant differences between three repeated measurements in pain threshold $(F(2,102)=1.68, p>$ $.05)$, pain tolerance $(F(2,102)=1.30, p>.05)$ and pain intensity $(F(2,102)=1.92, p>.05)$. The only statistically significant difference was the one suggesting an increase in pain unpleasantness $(F(2,102)=7.23, p<.01)$ between three repeated measurements; calculated effect size $\eta_{p}{ }^{2}$ $=0.12$ can be interpreted as medium ${ }^{24}$. Pairwise comparisons additionally described the obtained effect; the only difference proved to be statistically significant $(p<$ 0.05 ) was the one between the first and the third measurement. These results suggest that participants do not clearly perceive each following thermal measurement as more unpleasant, however - since thermal pain unpleasantness slowly increases with each measurement - authors are advised to avoid more than two repeated measurements.

Regarding the stability within the electrical pain context, results between three measurements remain the same only in pain intensity $(F(2,102)=0.39, p>.05)$, whilst pain threshold $\left(F(2,102)=3.63, p<.05 ; \eta_{p}^{2}=0.07\right)$, pain tolerance $\left(F(2,102)=47.14, p<.01 ; \eta_{p}^{2}=0.48\right)$ and pain unpleasantness $\left(F(2,102)=6.64, p<.01 ; \eta_{p}{ }^{2}=0.12\right)$ indicated successive increase with each new measurement. Pairwise comparisons demonstrated that pain thresh- 


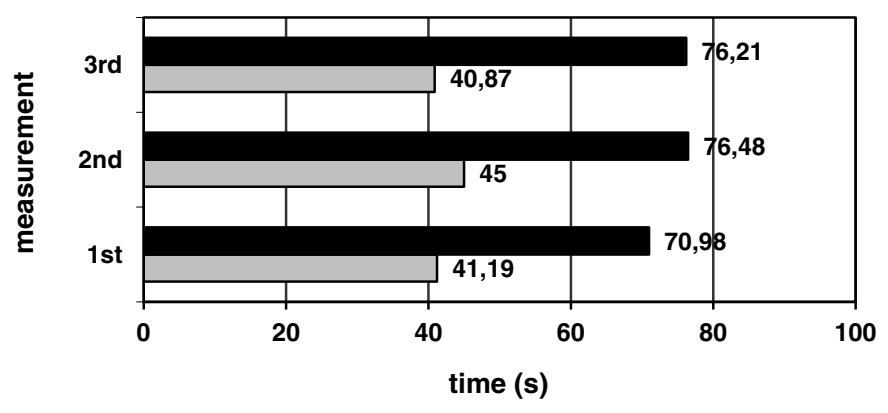

Dain tolerance

口pain threshold

Figure 1. Pain threshold and pain tolerance $(N=52)$ in thermal pain stimuli context obtained in three repeated measurements

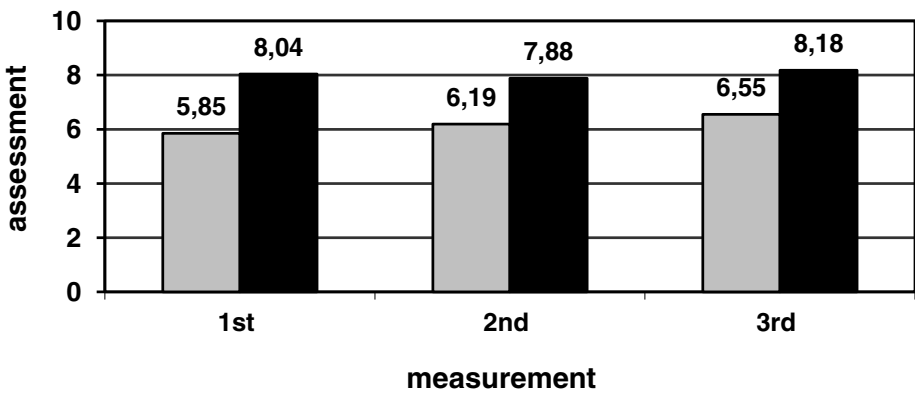

口pain unpleasantness

- pain intensity

measurement

Figure 2. Assessment of pain unpleasantness and pain intensity $(N=52)$ obtained in thermal pain stimuli context in three repeated measurements

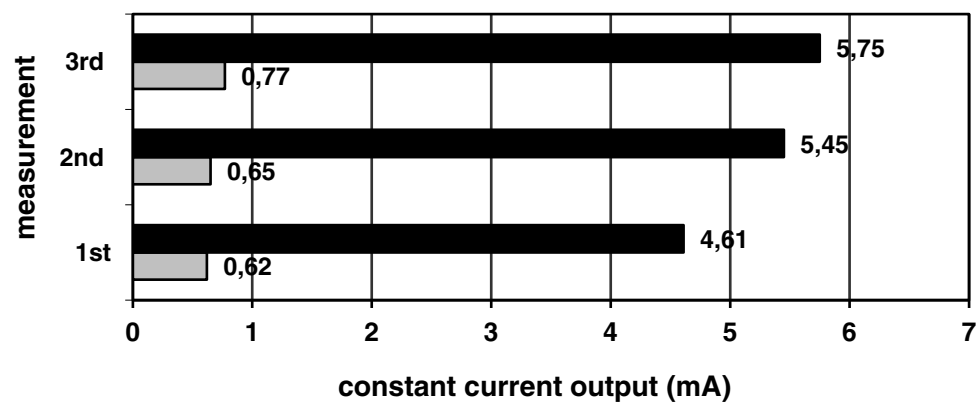

Dain tolerance

Figure 3. Pain threshold and pain tolerance $(N=52)$ obtained in electrical pain stimuli context in three repeated measurements

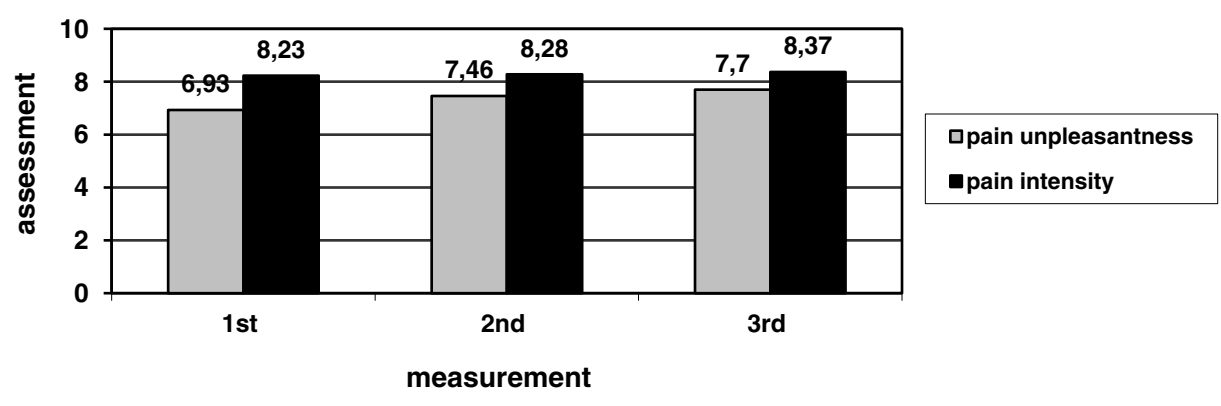

Figure 4. Assessment of pain unpleasantness and pain intensity $(N=52)$ obtained in electrical pain stimuli context in three repeated measurements 
old significantly differed only between the second and third measurement $(p<0.05)$, that pain tolerance differed between all three measurements $(p<0.01)$ and that pain unpleasantness significantly differed between the first and second, and also between the first and third measurement. One possible explanation of these results lies in the fact that participants probably had no previous experience with electrical stimuli (as opposed to extensive experience with thermal stimuli in everyday life) and were a bit anxious about it at first. They were cautious during their first contact with electrical stimuli, attentive to sense the very first sign of pain and reluctant to endure maximum pain till they were sure they would not be harmed. With each following measurement, they were more and more relaxed, confident and eager to test their limits, which ultimately matched higher pain unpleasantness assessment.

The existence of differences between repeated measurements in electrical pain context and lack of it between repeated measurements in thermal pain context suggest higher pain stability in thermal pain context. However, it would be inappropriate to conclude that electrical pain context is therefore not reliable - without consideration of correlation coefficients between repeated measurements in each variable, and also different dependent variables within the same measurement. Correlations among results obtained in each measured variable within three measurements, along with correlations among results obtained in all four measured variables within the thermal measurement context are presented in Table 1 . What stands out in this correlation matrix is that each of four measures has moderate to high correlations in three repeated measurements, which suggests that thermal pain perception is relatively stable within the same context. Additionally, all three measurements of thermal pain threshold and tolerance are proven to be mutually correlated - and the size of that correlation is generally highest between pain threshold and tolerance measured in the same day. The same results are obtained for all three measurements of thermal pain unpleasantness and intensity, different only in correlation sizes - which were somewhat lower, possibly due to the restricted range of assessments. Correlations between pain threshold/tol-

\begin{tabular}{|c|c|c|c|c|c|c|c|c|c|c|c|c|}
\hline & THR 1 & THR 2 & THR 3 & TOL 1 & TOL 2 & TOL 3 & UNP 1 & UNP 2 & UNP 3 & INT 1 & INT 2 & INT 3 \\
\hline THR 1 & 1 & $0.62^{\star \star}$ & $0.62^{\star \star}$ & $0.63^{\star \star}$ & $0.32^{*}$ & $0.31^{*}$ & -0.03 & -0.01 & 0.05 & 0.08 & 0.08 & 0.04 \\
\hline THR 2 & & 1 & $0.64^{\star \star}$ & $0.63^{\star \star}$ & $0.73^{\star \star}$ & $0.51^{\star \star}$ & 0.12 & 0.09 & 0.22 & $0.33^{*}$ & 0.02 & 0.23 \\
\hline THR 3 & & & 1 & $0.47^{\star \star}$ & $0.46^{\star *}$ & $0.60^{\star \star}$ & -0.13 & -0.11 & -0.17 & -0.03 & -0.12 & -0.07 \\
\hline TOL 1 & & & & 1 & $0.73^{\star \star}$ & $0.64^{\star \star}$ & 0.10 & 0.10 & 0.15 & $0.28^{*}$ & 0.18 & 0.26 \\
\hline TOL 2 & & & & & 1 & $0.72^{\star \star}$ & 0.11 & 0.12 & 0.26 & $0.40^{* *}$ & 0.14 & $0.36^{\star *}$ \\
\hline TOL 3 & & & & & & 1 & -0.07 & -0.07 & -0.02 & 0.16 & 0.08 & 0.21 \\
\hline UNP 1 & & & & & & & 1 & $0.68^{\star \star}$ & $0.65^{\star \star}$ & $0.36^{\star \star}$ & $0.39^{\star \star}$ & $0.28^{\star}$ \\
\hline UNP 2 & & & & & & & & 1 & $0.75^{\star \star}$ & $0.30^{*}$ & $0.47^{\star \star}$ & $0.35^{\star}$ \\
\hline UNP 3 & & & & & & & & & 1 & $0.31^{*}$ & $0.40^{* *}$ & $0.48^{\star *}$ \\
\hline INT 1 & & & & & & & & & & 1 & $0.59^{\star \star}$ & $0.65^{\star *}$ \\
\hline INT 2 & & & & & & & & & & & 1 & $0.80^{\star *}$ \\
\hline INT 3 & & & & & & & & & & & & 1 \\
\hline
\end{tabular}


erance and pain unpleasantness/intensity - even within the same-day measurement were virtually non-existent, which suggests that pain threshold and tolerance measure one aspect of pain (sensory-discriminative), while pain unpleasantness and intensity measure the other (affective-motivational). This is not in accordance with previous findings ${ }^{25-26}$ suggesting high correlations between sensory and affective components of pain, especially in experimental settings.

Correlations among the results obtained in each measured variable within three measurements, along with correlations among results obtained in all four measured variables within the electrical measurement context are presented in Table 2. Here we can see the electrical pain context following the same pattern as the thermal one - all four pain measures have moderate to high correlations in three repeated measurements; pain tolerance and pain intensity being even higher in electrical pain stimuli context. Therefore it would be inappropriate to conclude that electrical pain perception is not reliable. Instead, it is possible that electrical pain perception is additionally influenced by some other fac- tor (e.g. fear of electrical shock). This is supported by the observation that individuals who undergo training as subjects for electrical stimulation have increased their threshold as high as 300\% and tolerances 350\% ${ }^{27,28}$. Such possible influence would explain the observed differences in electrical pain threshold, tolerance, and unpleasantness between repeated pain measurements and also much lower correlations among measures of sensory-discriminative (threshold and tolerance) and affective-motivational (unpleasantness and intensity) aspect of electrical pain experience within the same measurement and especially between three repeated measurements.

In the context of two pain modalities, obtained results are similar considering the assessment of pain intensity - which does not change within measurements, and also the assessment of pain unpleasantness - which increases with each following measurement in both thermal and electrical context. However, when the pain was induced by thermal stimuli, both pain unpleasantness and intensity were assessed lower than they were assessed in the situation of electrical pain stimuli. These

Table 2. Correlations among results $(\boldsymbol{N}=52)$ obtained in each measured variable (pain threshold-THR, pain tolerance-TOL, pain unpleasantness-UNP and pain intensity-INT) within all three repeated measurements in electrical pain stimuli context

\begin{tabular}{|c|c|c|c|c|c|c|c|c|c|c|c|c|}
\hline & THR 1 & THR 2 & THR 3 & TOL 1 & TOL 2 & TOL 3 & UNP 1 & UNP 2 & UNP 3 & INT 1 & INT 2 & INT 3 \\
\hline THR 1 & 1 & $0.57^{\star \star}$ & $0.54^{\star \star}$ & 0.00 & 0.16 & 0.18 & 0.01 & -0.03 & -0.26 & -0.10 & -0.17 & -0.14 \\
\hline THR 2 & & 1 & $0.80^{\star \star}$ & 0.24 & $0.30^{\star}$ & $0.35^{\star}$ & -0.14 & -0.22 & $-0.29^{*}$ & -0.11 & -0.16 & -0.18 \\
\hline THR 3 & & & 1 & 0.17 & 0.20 & $0.31^{\star}$ & -0.06 & -0.13 & & -0.13 & -0.14 & -0.12 \\
\hline TOL 1 & & & & 1 & $0.87^{\star \star}$ & $0.85^{\star *}$ & -0.14 & -0.04 & 0.22 & 0.26 & $0.31^{\star}$ & $0.34^{\star}$ \\
\hline TOL 2 & & & & & 1 & $0.93^{\star \star}$ & -0.15 & -0.11 & 0.18 & 0.13 & 0.23 & 0.22 \\
\hline TOL 3 & & & & & & 1 & -0.14 & -0.10 & 0.07 & 0.16 & $0.29^{\star}$ & $0.31^{\star}$ \\
\hline UNP 1 & & & & & & & 1 & $0.64^{\star *}$ & $0.43^{\star *}$ & $0.31^{\star}$ & 0.21 & 0.20 \\
\hline UNP 2 & & & & & & & & 1 & $0.52^{\star \star}$ & $0.33^{*}$ & $0.31^{\star}$ & 0.18 \\
\hline UNP 3 & & & & & & & & & 1 & 0.26 & $0.33^{*}$ & $0.29^{*}$ \\
\hline INT 1 & & & & & & & & & & 1 & $0.70^{\star \star}$ & $0.69^{* *}$ \\
\hline INT 2 & & & & & & & & & & & 1 & $0.87^{\star \star}$ \\
\hline INT 3 & & & & & & & & & & & & 1 \\
\hline
\end{tabular}


results, together with findings of no difference in thermal pain threshold and tolerance and increased electrical pain threshold and tolerance in repeated measurements, suggest that a reason for what appears to be instability of results in electrical stimuli context might be found in different characteristics of these two pain inducement methods.

More specifically, thermal pain inducement evokes natural sensation whilst electrical pain inducement evokes non-natural sensation. This is supported by participants' statement that they find electrical stimuli hard to define as painful and described highest electrical stimuli (pain tolerance) as extremely unpleasant. Low to moderate correlations between thermal and electrical pain tolerance (between $r=.27$ and $r=.54$ ), and intensity (between $r=.28$ and $r=.53$ ), and non-existing correlations between thermal and electrical pain threshold and unpleasantness also speak in favour of conclusion that what is being measured in these two stimuli contexts in not the same thing. Some authors ${ }^{29}$ who found no correlations between different experimental pain modalities suggest that reactions to different ways of pain inducement represent different dimensions and advocate the importance of multi-modal approach in pain research.

Also, another attribute that could contribute to obtained differences between thermal and electrical pain stimuli context is familiarity with specific stimuli and different level of anxiety associated with it. Participants, in everyday life, are more likely to have experience with thermal (e.g. hot oven, boiled water, cigarette burn) but not with electrical pain context, which makes them insecure of what to expect from the situation and themselves - which could explain for the lowest pain threshold and tolerance in the first measurement. Since all the results show the same increasing trend it is impossible to predict whether the following four, five or even ten measurements would continue with this trend; therefore, further studies are needed to investigate at what point (number of repeated measurements) do pain measures in electrical stimuli context achieve their plateau, and to investigate whether that would become a permanent or just a temporary change for one participant. Since real clinical settings include numerous painful medical procedures, usually unfamiliar to most of the patients - it is possible that patients react the same way, tending to overestimate the painfulness of the procedure when facing it for the first time.

\section{Methodological considerations}

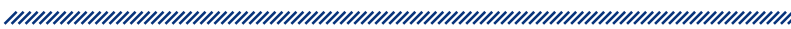

There are several methodological issues one must consider concerning this study. First, the study was conducted on the convenient sample, therefore we cannot be sure that participants with e.g. different age or gender would perceive the thermal and electrical pain stimuli equally. To ensure greater external validity, further studies should focus on different, preferably larger and more heterogeneous samples. Next, no information considering menstrual cycle phase was obtained in the present experiment, though there are some indications $^{27}$ that this is also a factor that affects pain sensitivity. Additionally, participants were not asked if they were left- or right-handed though, according to some authors ${ }^{30}$, dexterity might influence hand-sensitivity. Also, since familiarity of pain modalities turned out to be a possible confounding variable, further studies should include at least several pre-measurements (that would not be taken into the statistical analysis) in order to reduce or eliminate its possible effect. Finally, the study focused only on the perception of thermal and electrical pain experience but neglected to investigate other frequently used pain modalities (e.g. mechanical) - which would be advisable to include in the future studies.

\section{General implications}

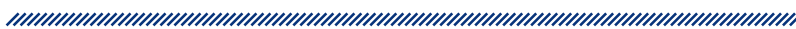

Present findings contribute to pain research by indicating that stability of pain perception depends on both stimuli context and type of pain measure. More specifically, understanding that people will not react the same way to different pain modalities provokes the researcher to carefully consider which pain modality to use and which pain measures to include in the following study. Present research not only informs about the different stability of pain perception but it also signals which measures are more inclined to be under influence of some systematic factors - indicating an increased need for control. For example, if one would like to test the effect of some variable on the pain perception using dependent sample design - rotation design would 
be mandatory in electrical pain modality and only optional in thermal pain modality. And the findings lead to some practical advice: when conducting pain research consider the multi-method approach, but only if there are indications that it will improve your research and strengthen your conclusions rather than complicate both of them.

\section{Conclusions}

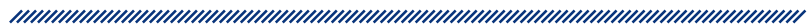

Results of the study demonstrate that stability of pain perception depends on both stimuli context and the type of pain measurement. With regards to pain modality, pain experience was proven to be more stable in thermal-stimuli context as three out of four pain measures (pain threshold, pain tolerance, and pain intensity) remained unchanged between three measurement points. In electrical-stimuli context, only the assessment of pain intensity remained the same, while pain threshold and tolerance, together with the assessment of pain unpleasantness successively increased with each following measurement. Moderate to high correlations in three repeated measurements in both modalities suggest that neither method is less reliable but that electrical pain perception is more influenced by some other factor (e.g. anxiety related to the unfamiliarity of pain stimuli) related to the previous measurement experience. Authors of the future studies are advised to take into account the characteristics of each pain-inducement and pain measurement method when considering the multi-method approach.

\section{References}

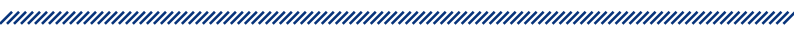

1. Edwards RR, Fillingim RB. Age-associated differences in responses to noxious stimuli. Journals of gerontology: biological sciences and medical sciences. 2001; 56: 180-185.

2. Edwards RR, Fillingim RB, Ness TJ. Age-related differences in endogenous pain modulation: a comparison of diffuse noxious inhibitory controls in healthy older and younger adults. Pain. 2003; 101: 155-165.

3. Unruh AM. Gender variations in clinical pain experience. Pain. 1996; 65: 123-167.

4. Riley III JL, Robinson ME, Wise EA, Myers CD, Fillingim RB. Sex differences in the perception of noxious experimental stimuli: a meta-analysis. Pain. 1998; 74: 181-187.

5. Bachiocco V, Scesi M, Morselli AM, Carli G. Individual pain history and familial pain tolerance models: relationships to post-surgical pain. The clinical journal of pain. 1993; 9(4): 266-271.

6. Dar R, Ariely D, Frenk H. The effect of past-injury on pain threshold and tolerance. Pain. 1995; 60: 189-193.

7. Arntz A, Dreessen L, Marckelbach H. Attention, not anxiety, influences pain. Behaviour Research and Therapy. 1991; 29(1): 41-50.

8. Arntz, A, de Jong P. Anxiety, attention and pain. Journal of Psychosomatic Research. 1993; 37(4): 423-431.

9. Ploghaus A, Becerra L, Borras C, Borsook D. Neural circuitry underlying pain modulation: expectation, hypnosis, placebo. Trends in Cognitive Science. 2003; 7: 197-200.

10. Koyama T, McHaffie JG, Laurienti PJ, Coghill RC. The subjective experience of pain: Where expectations become reality. Proceedings of the National Academy of Sciences of the United States of America. 2005; 102 (36): 1295012955.

11. Tse MMY, Ng JKF, Chung JWY, Wong TKS. The effect of visual stimuli on pain threshold and tolerance. Journal of Clinical Nursing. 2002; 11: 264-269.

12. Walch JM., Rabin BS, Day R, Williams JN, Choi K, Kang JD. The effect of sunlight on postoperative analgesic medication use: A prospective study of patients undergoing spinal surgery. Psychosomatic Medicine. 2005; 67: 156-163.

13. Kállai I, Barke A, Voss U. The effects of experimenter characteristics on pain reports in women and men. Pain. 2004; 112 (1-2): 142-147.

14. Williams DA., Park KM., Ambrose KR, Clauw DJ. Assessor status influences pain recall. The Journal of Pain. 2007; 8(4): 343-348.

15. Norbury TA, MacGregor AJ, Urwin J, Spector TD, McMahon SB. Heritability of responses to painful stimuli in women: a classical twin study. Brain. 2007; 130: 3041-3049.

16. Koltzenburg M, Handwerker HO. Differential ability of human cutaneous nociceptors to signal mechanical pain and to produce vasodilatation. The Journal of Neuroscience. 1994; 14 (3): 1756-1765. 
17. Chéry-Croze S. Painful sensation induced by a thermal cutaneous stimulus. Pain. 1983; 17 (2): 109-137.

18. Pool GJ, Schwegler AF, Theodore BR, Fuchs PN. Role of gender norms and group identification on hypothetical and experimental pain tolerance. Pain. 2007; 129: 122-129.

19. Brown JE, Chatterjee N, Younger J, Mackey S. Towards a Physiology-Based Measure of Pain: Patterns of Human Brain Activity Distinguish Painful from Non-Painful Thermal Stimulation. PLoS ONE, 2011; 6 (9): e24124 DOI: 10.1371/journal.pone.0024124

20. Mullan B, Todd J, Chatzisarantis NL, Hagger MS. Experimental methods in health psychology in Australia: Implications for applied research. Australian Psychologist. 2014; 49(2): 104-109.

21. Hastie BA, Riley JL, Robinson ME, Glover T, Campbell CM, Staud R, Fillingim RB. Cluster analysis of multiple experimental pain modalities. Pain. 2005; 116(3): 227-237.

22. Levine FM, de Simone LL. The effects of experimenter gender on pain report in male and female subjects. Pain. 1991; 44 (1): 69-72.

23. Modić Stanke K, Ivanec D. Pain threshold - Measure of pain sensitivity or social behaviour? Psihologija. 2016; 49 (1): 37-50.

24. Cohen, J. Statistical Power Analysis for the Bihevioral Sciences, 2nd Ed. Hillsdale, NJ: Lawrence Erlbaum Associates, 1988. 283-287.
25. Price DD, Harkins SW, Baker C. Sensory-affective relationships among different types of clinical and experimental pain. Pain. 1987; 28: 297-308.

26. Rainville P, Feine JS, Bushnell MC, Duncan GH. A psychophysical comparison of sensory and affective responses to four modalities of experimental pain. Somatosensory and Motor Research, 1992; 9 (4): 265-277.

27. Riley III JL, Robinson ME, Wise EA, Price DD. A metaanalytic review of pain perception across the menstrual cycle. Pain, 1999; 81: 225-235.

28. Vierck CJ, Cooper BY, Cohen RH. Human and nonhuman primate reactions to painful electrocutaneous stimuli and to morphine. In: Kitchell RL, Erickson $\mathrm{HH}$, editors. Animal Pain: Perception and Alleviation. Bethesda: American Physiological Society, 1983. 117- 122.

29. Neziri AY, Curatolo M, Nüesch E, Scaramozzino P, Andersen OK, Arendt-Nielsen L, Jüni P. Factor analysis of responses to thermal, electrical, and mechanical painful stimuli supports the importance of multi-modal pain assessment. Pain, 2011; 152: 1146-1155.

30. Özcan A, Tulum Z, Pınar L, Başkurt F. Comparison of pressure pain threshold, grip strength, dexterity and touch pressure of dominant and non-dominant hands within and between right-and left-handed subjects. Journal of Korean Medical Science, 2004; 19 (6), 874-878. 


\section{STABILNOST MJERA BOLI U RAZLIČITOM PODRAŽAJNOM KONTEKSTU}

1 Koraljka Modić Stanke

1 Odsjek za psihologiju, Filozofski fakultet Sveučilišta u Zagrebu, Zagreb

\section{Sažetak}

Doživljaj boli u bilo kojem kontekstu povezan je s velikom inter- i intra-individualnom varijabilnošću. $U$ eksperimentalnim uvjetima istraživačima na raspolaganju stoji nekoliko metoda za izazivanje boli, kao i niz načina mjerenja iste. Budući da nijedna metoda nije bez nedostataka, u posljednje se vrijeme sve više istraživača odlučuje na istovremeno korištenje više metoda izazivanja i mjerenja boli. Jasnost i jednoznačnost rezultata pritom može varirati - ovisno o pouzdanosti pojedinih mjera u određenom podražajnom kontekstu.

Cilj istraživanja bio je ispitati stabilnost percepcije boli kod istih sudionika - kako u različitom podražajnom kontekstu, tako i unutar istog s protokom vremena. U istraživanju su sudjelovale 52 studentice koje su u razmacima od tjedan dana prolazile tri metodološki identična ponovljena mjerenja na kojima im se bol zadavala na dva načina - prvo toplinskim, a nakon toga električnim impulsima. Sudionice su tijekom svakog podraživanja izvještavale o pragu i toleranciju boli, a nakon svakog podraživanja procjenjivale su intenzitet i neugodu boli.

Rezultati su pokazali da stabilnost percepcije boli ovisi o podražajnom kontekstu i načinu mjerenja boli. Do- življaj boli pokazao se stabilnijim prilikom toplinskog podraživanja gdje su se prag i tolerancija boli pokazali jednakima u sva tri mjerenja. Prilikom električnog podraživanja sa svakim sljedećim mjerenjem pokazao se statistički značajan porast u pragu i toleranciji boli. U oba podražajna konteksta procjena intenziteta boli ostala je konstantna kroz sva tri mjerenja, dok je procjena neugode boli statistički značajno rasla. Opažene kontekstualne razlike mogu se objasniti različitom upoznatosti sudionika sa pojedinim načinom izazivanja boli te s tim povezanom različitom razinom anksioznosti.

Ključne riječi: stabilnost percepcije boli, prag boli, tolerancija boli, neugoda boli, intenzitet boli, toplinsko i električno podraživanje 